\title{
Preliminary Study on Seedling Growth Rhythm and Grey Correlation Analysis of Rubber (Hevea brasiliensis) Seedlings in Danzhou District, Hainan
}

\author{
Dongling Qi, Chuan Yang, Guishui Xie, Zhixiang $\mathbf{W u}^{*}$ \\ Rubber Research Institute, Chinese Academy of Tropical Agricultural Sciences/Danzhou Investigation \& \\ Experiment Station of Tropical Crops, Ministry of Agriculture, Danzhou, China \\ Email: zhixiangwu@21cn.com
}

Received 7 November 2014; revised 1 December 2014; accepted 10 December 2014

Copyright $@ 2014$ by authors and Scientific Research Publishing Inc.

This work is licensed under the Creative Commons Attribution International License (CC BY). http://creativecommons.org/licenses/by/4.0/

(c) (i) Open Access

\begin{abstract}
The rubber tree physiological and ecological process quantitatively described by using mathematical method is an important means to the analysis of rubber tree growth process and mechanism. The study on growth simulation model of rubber tree will lay the foundation for the application of rubber tree cultivation intelligent decision system. A Richards equation was formulated to describe the height and stem diameter growth dynamics of the annual rubber seedlings. An area correlation analysis was done according to the closeness of the observed parameters to the dynamic curve on the gray system composed of the seedling growth increment and the meteorological factors including aerial temperature, precipitation and solar radiation hours that influence upon the seedling growth. The results showed that rubber seedling response fitted the Richards equation quite well. The growth increment displayed a distinct alternation of "slow-fast-slowfast-slow" rhythm. The growth course of the seedlings might be partitioned into three periods of time by the sequential clustering analysis, namely pre-growing, fast-growing, late-growing stage. The tray correlation analysis revealed that air temperature had the most significant influence while precipitation had the least impact on height growth of the rubber seedlings. In conclusion, the air temperature had the most significant influence while solar radiation hours had the least impact on stem diameter growth of the rubber seedlings.
\end{abstract}

\section{Keywords}

Rubber (Hevea brasiliensis), Richards Equation, Growth Rhythm, Gray Correlation

\footnotetext{
*Corresponding author.
}

How to cite this paper: Qi, D.L., Yang, C., Xie, G.S. and Wu, Z.X. (2014) Preliminary Study on Seedling Growth Rhythm and Grey Correlation Analysis of Rubber (Hevea brasiliensis) Seedlings in Danzhou District, Hainan. American Journal of Plant Sciences, 5, 3866-3872. http://dx.doi.org/10.4236/ajps.2014.526404 


\section{Introduction}

Height growth and diameter growth is an important part in vegetative growth of crops, the growth of the pros and cons is directly related to crop growth and yield quality. The vegetative growth of rubber tree (Hevea brasiliensis) mainly includes the stem diameter and the height growth, which is main index to measure the rubber tree growth, forest uniformity, whether rubber trees reach the standard for open tapping, but also an important basis for rubber production technology and economic management [1]. Therefore, it is very meaningful to study the growth rhythm of rubber tree diameter and height growth. Construction of growth model is an effective way to quantitative research of crop growth dynamic process; the method of mathematical analysis and mathematical analysis models are more and more applied to agricultural fields [2]-[5]. Studying on dynamic and related model of rubber tree growth, some scholars have carried out some research work; rubber tree girth growth model was respectively established, and Richards model was considered good for simulating rubber tree growth [6] [7]. Rubber tree root model was constructed [8] [9]. Mathematical model between the per area yield of dry rubber and rubber tapping tree was established [10]. Zhou and Tang established the estimation model of rubber tree biomass [11] [12]. Model to predict the per unit area yield rubber was established [13]. Mathematical model of photosynthetic capacity estimation of Hevea population and rubber tree canopy photosynthesis simulation model were built [14] [15]. Above scholars research results in fitting rubber tree growth has made gains. At present, rubber seedlings period of high growth and diameter growth dynamic rhythm still have little understanding; cultivating robust seedling is the foundation of rubber seedling production. Study on growth regularity of seasonal variation of rubber seedling will not only help to deepen understand rubber saplings growth rhythm, but also provide the reference basis for field cultivation and management measures to carry out the scientific seedling. This article studies the high growth and stem diameter changes of rubber seedlings by the observing of fixed plant and fixed time. In addition, some main environment factors influence of rubber seedlings growth will be analyzed with the correlation of rubber seedling growth. The results will produce reference for the rubber tree seedling cultivation and production.

\section{Material and Methods}

\subsection{General Situation of Test Area}

The study area is located in the Chinese Academy of Tropical Agricultural Sciences rubber tree seed and seedling breeding base in the nursery, Danzhou city in the west of Hainan Province, and which is located in north latitude $19^{\circ} 29^{\prime \prime}$ and east longitude $109^{\circ} 28^{\prime \prime}$. This area belongs to subtropical monsoon climate zone, high temperature and rainy, hot and humid season, the annual average temperature of $23^{\circ} \mathrm{C}-25^{\circ} \mathrm{C}$, the lowest average temperature $17^{\circ} \mathrm{C}-18^{\circ} \mathrm{C}$ greater than $10^{\circ} \mathrm{C}$ is annual accumulated temperature of $8700^{\circ} \mathrm{C}$; the average annual rainfall of $1500-1900 \mathrm{~mm}$.

\subsection{Study Material}

October 17, 2012 sowing, November 15 after transplanting into the sand bed nursery germination, spacing 50 $\mathrm{cm} \times 25 \mathrm{~cm}$, nursery stock in accordance with conventional management.

Sunshine hours, rainfall, air temperature and other meteorological factors from Danzhou Investigation \& Experiment Station of Tropical Crops, Ministry of Agriculture, P.R. China collected observational data used in this assay late associate degree analysis.

\subsection{Rubber Seedlings Observation and Data Processing}

This study uses a randomized complete block design with four rows of each plot design, repeated five times. Each plot measured in the middle two rows, each row measuring 4 lines. Steel tape measure height point seedlings at $5 \mathrm{~cm}$ from the ground, as girth growth of fixed measurement position and marked with paint, with a vernier caliper to measure the degree of stem diameter. On April 7, every 15 days, respectively, to measure its height and circumference diameter, observed on July 21 deadline (i.e. the day of observation after budding), DPS data using observation data software for statistical analysis [16].

\subsection{Rubber Seedlings Height and Stem Diameter Growth Curve Fitting}

Richards equation chosen height and stem diameter growth of rubber seedlings were fitted, which was expressed 
as follows:

$$
Y=A /(1+B e-K t)^{1} / N
$$

In the above formula, $A, B, K, N$ is the growth parameters. $A$ is the amount of growth of the final value, and represents the blending coefficient is determined using the appropriate $\mathrm{R}^{2}$. Where $Y$ is accumulation of rubber seedling growth, and $t$ is the rubber seedlings growth days.

\subsection{Relational Analysis Rubber Seedlings between Main Meteorological Factors}

Height and stem diameter rubber seedlings and net growth for the mother sequence $\mathrm{X}_{0}$, sunshine, precipitation, temperature of the sub-sequence $X_{i}(i=1-3)$, rubber seedling growth and meteorological factors to form a gray system. The resulting rubber seedlings observations and meteorological data were standardized data conversion software using DPS gray correlation analysis [16].

\section{Results}

\subsection{Rubber Seedlings High and Stem Diameter Growth}

Based on actual observations of rubber seedlings, rubber seedling growth showing a clear "slow—fast—slowfast—slow" growth trend (Figure 1 and Figure 2). Two rubber seedlings grown peak occurred. Rubber seedlings in March slower growth, growth accelerated in early May, late May to reach first a growth peak. Then rubber seedling growth slowed in mid-June growth accelerated again in late June to achieve the first two growth peak. Rubber seedlings roughness height and girth of observational data, rubber seedlings high growth and stem diameter growth model was build (Table 1 ).

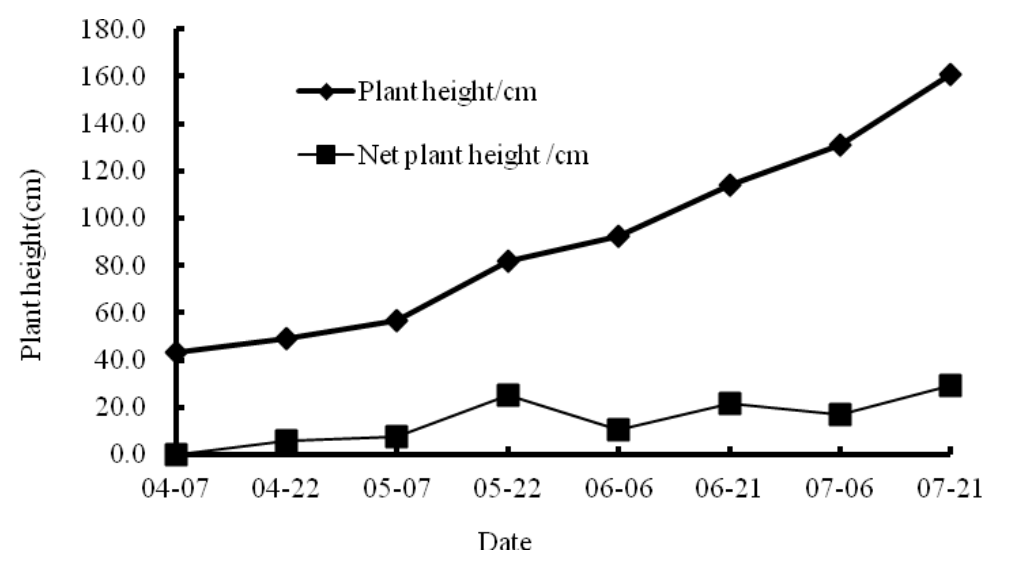

Figure 1. Growth process of plant height of rubber seedlings.

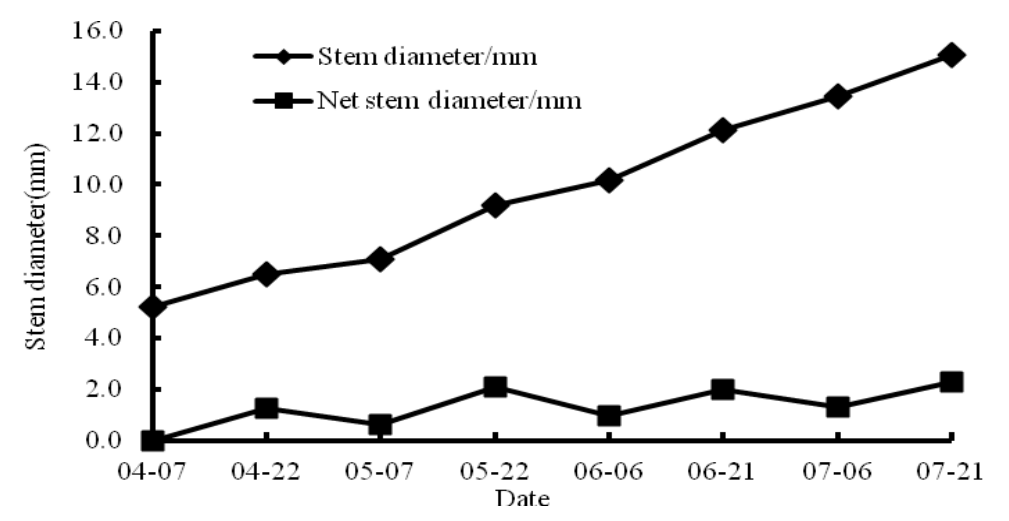

Figure 2. Growth process of stem diameter of rubber seedlings. 
Table 1. Growth model for plant height and stem diameter of rubber seedlings.

\begin{tabular}{|c|c|c|c|c|c|c|c|}
\hline & Regression equation & Sources of variance & Quadratic sum & df & Mean square & F value & $P$ value \\
\hline \multirow{4}{*}{$\begin{array}{l}\text { Plant } \\
\text { height }\end{array}$} & \multirow{4}{*}{$y=214.8356 /(1+12.9757 e-0.026319 t)(1 / 1.5445)$} & Return variance & 12762.19 & 3 & 4016.194 & 57.0962 & 0.0011 \\
\hline & & $\begin{array}{l}\text { Remaining } \\
\text { variance }\end{array}$ & 312.8671 & 4 & 74.1526 & \multirow{7}{*}{59.1547} & \multirow{7}{*}{0.0011} \\
\hline & & $\begin{array}{c}\text { Total } \\
\text { variance }\end{array}$ & 12882.35 & 7 & 1860.974 & & \\
\hline & & $\mathrm{R}=0.9881$ & $\mathrm{R}^{2}=0.9763$ & & & & \\
\hline \multirow{4}{*}{$\begin{array}{c}\text { Stem } \\
\text { diameter }\end{array}$} & \multirow{4}{*}{$y=24.3239 /(1+16.6999 e-0.024609 t)(1 / 1.8398)$} & $\begin{array}{c}\text { Return } \\
\text { variance }\end{array}$ & 102.7231 & 3 & 34.241 & & \\
\hline & & $\begin{array}{l}\text { Remaining } \\
\text { variance }\end{array}$ & 2.6228 & 4 & 0.6483 & & \\
\hline & & Total variance & 112.4332 & 7 & 15.4637 & & \\
\hline & & $\mathrm{R}=0.9881$ & $\mathrm{R}^{2}=0.9764$ & & & & \\
\hline
\end{tabular}

\subsection{Fitting and Stem Diameter Rubber Seedlings High Growth Curve}

Rubber seedling height, stem diameter growth fitting curves in Figure 3 and Figure 4, and the results shows the high and stem diameter rubber seedlings and actual observations made by the growth curve fitting curve consistent with the predicted values is high, the coefficient of determination, respectively, $97.63 \%$ and $97.64 \%$, and the choice of Richards curve can be well fitted rubber seedlings height and stem diameter growth.

\subsection{Division and Stem Diameter Rubber Seedlings High Growth Period}

Daily growth rate of height and stem diameter for rubber seedlings was clustered under DPS environment using cluster analysis of samples ordered optimal segmentation method. The growth process of rubber seedlings high and stem diameter combined with rubber seedling growth characteristics was divided for the three growth stages, namely the growth of the early, fast-growing and late growth stage. According to these stages, the cumulative amount of growth of rubber seedling height and growth of stem diameter each growing stage was calculated (Table 2).

\subsection{Rubber Seedlings High Correlation Analysis and Stem Diameter Growth with Major Meteorological Factors}

Rubber height growth, coarse gray correlation analysis between growth and meteorological factors indicated the presence of various meteorological factors affecting growth and high growth dynamics crude differences, where the greatest impact on the temperature and precipitation minimal impact on high growth. The maximum temperature on the stem diameter growth, precipitation minimal impact (Table 3).

\section{Discussion}

This study results showed that height growth and diameter growth of rubber seedlings showed "slow—fast— slow - fast - slow” rhythm changes, fast-growing stage of two grown significantly during the peak growing time peak appeared in mid-May and mid-June to late, respectively. The results were similar with the growth of other forest seedlings [17] [18]. The growth of rubber tree in young period was a rhythmic growth [19] [20]. Annual girth growth of rubber tree in the mature phases showed stability, and the stability of annual girth growth correlated negatively with the stability of yield [21]. A logistic equation was fitted to girth data of rubber tree in order to assess intercropping effect in immature period [22]. At present, this seasonal girth of rubber tree was reported less. But there were report about the annual change of rubber trees growth. Stem diameter growth of rubber clone CATAS7-33-97 from 1 year to 7 years presented regular linear growth [23]. The relationship between Ivorian rubber plantation rubber tree girth growth and open tapping time was studied, and the results showed that the sixth years after planting rubber trees, the cumulative amount of stem diameter girth could reach standards of tappability [6]. The characteristics of inter annual change around India's major cultivar RRII 105 growth rate after planting for second to twelfth years firstly increased and then decreased [7]. In this study, 


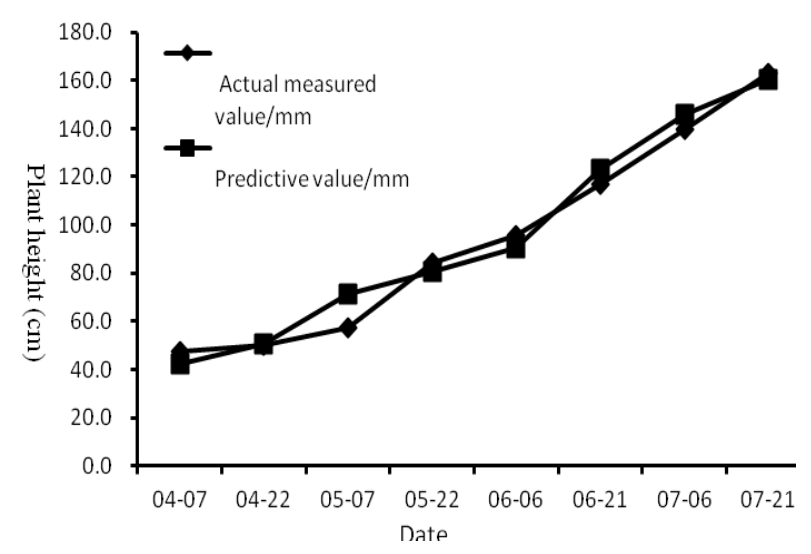

Figure 3. The fitting curve of height growth of rubber seedlings.

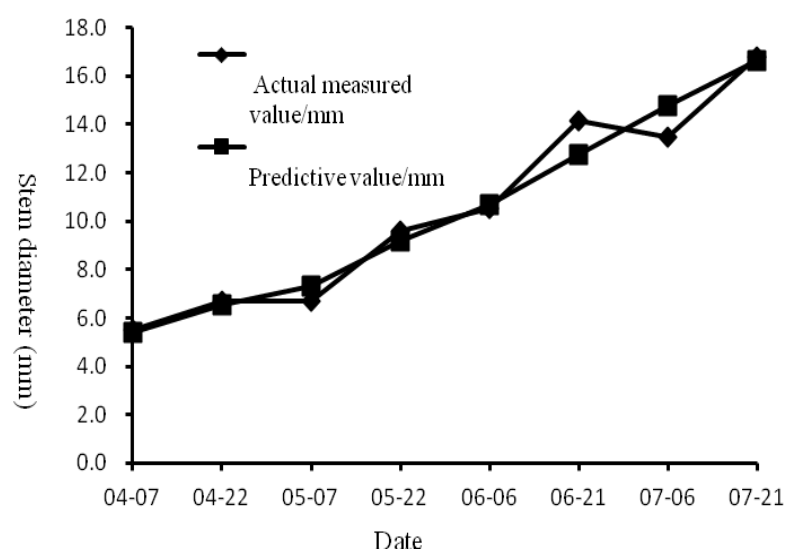

Figure 4. The fitting curve of stem diameter of rubber seedlings.

Table 2. The division of growth period and growth compare of rubber seedlings.

\begin{tabular}{cccccc}
\hline \multirow{2}{*}{ Item } & Growth period & $\begin{array}{c}\text { Starting and } \\
\text { ending date }\end{array}$ & Cumulative time/d & Net growth/cm & $\begin{array}{c}\text { Proportion of the } \\
\text { total amount }\end{array}$ \\
\hline \multirow{3}{*}{ Plant height } & Pre-growth stage & $04-07-05-07$ & 30 & 13.25 & 10.83 \\
& Fast-growing stage & $05-08-07-06$ & 60 & 74.65 & 61.00 \\
& Late-growth stage & $07-07-07-21$ & 15 & 34.47 & 28.17 \\
Stem & Pre-growth stage & $04-07-05-07$ & 30 & 0.18 & 17.48 \\
& Fast-growing stage & $05-08-07-06$ & 60 & 0.63 & 61.17 \\
& Late--growth stage & $07-07-07-21$ & 15 & 0.22 & 21.36 \\
\hline
\end{tabular}

Table 3. Analysis of rubber seedling height growth, diameter growth and meteorological factor correlation.

\begin{tabular}{ccccccc}
\hline & Plant eight & & \multicolumn{2}{c}{ Stem diameter } \\
\hline Item & $\begin{array}{c}\text { Aerial } \\
\text { temperature } /{ }^{\circ} \mathrm{C}\end{array}$ & $\begin{array}{c}\text { Precipitation } \\
/ \mathrm{mm}\end{array}$ & $\begin{array}{c}\text { Solar radiation } \\
\text { hours/h }\end{array}$ & $\begin{array}{c}\text { Aerial } \\
\text { temperature } /{ }^{\circ} \mathrm{C}\end{array}$ & $\begin{array}{c}\text { Precipitation/mm } \\
\text { Solar radiation } \\
\text { hours } / \mathrm{h}\end{array}$ & 0.2165 \\
\hline $\begin{array}{c}\text { Correlation degree } \\
\text { Sequencing }\end{array}$ & 0.2383 & 0.1793 & 0.2171 & 0.4399 & 219 & 0.219 \\
\hline
\end{tabular}

growth rhythm of rubber seedlings was studied using fixed point and fixed line, from the seasonal variation of the angle.

This article only region of Hainan Danzhou dynamic growth rhythm of rubber seedlings were studied, whether the results are applicable to other parts of the rubber seedlings, pending further carry out related re- 
search. In addition, growth period in this paper only between April 7 to July 21, the results reflect only the rhythm of this phase of growth, in order to fully understand the seedling growth rhythm, an annual cycle period will be further selected.

\section{Conclusion}

The results of this study showed that rubber seedlings plant height and stem diameter presented the growth rhythm "slow_fast_slow_fast_-slow". The growth course of the seedlings might be partitioned into three periods of time by the sequential clustering analysis, namely pre-growing, fast-growing, late-growing stage. The tray correlation analysis revealed that air temperature had the most significant influence while precipitation had the least impact on height growth of the rubber seedlings. The air temperature had the most significant influence while solar radiation hours had the least impact on stem diameter growth of the rubber seedlings.

\section{Acknowledgements}

The authors are thankful to China Agriculture Research System (CARS-34-GW5) for providing financial support.

\section{References}

[1] Wu, J.L. (2007) Study on Stem Diameter Growth of Rubber Tree. Journal of Hainan State Farm Science and Technology, 2, 7-15.

[2] Thierry, F., Zhang, X.P., Alexia, S., Hans, L. and Christian, K. (2008) Plant Growth Modelling and Applications: The Increasing Importance of Plant Architecture in Growth Models. Annals of Botany, 101, 1053-1063. http://dx.doi.org/10.1093/aob/mcn050

[3] Liu, Y., Kang, X.G., Guo, Y.R., Tie, N., Gao, X. and Zhao, D.N. (2014) A Study on Stand Growth Process for Three Dominant Forest Types in Changbai Mountain. Journal of Nanjing Forestry University (Natural Science Edition), 38, 63-67.

[4] Zheng, J.P., Fan, C.N., Guo, Z.L., Yang, B.G. and Yue, L. (2014) Fine Roots Biomass and Its Dynamics of Larix Olgensis Plantation. Journal of Nanjing Forestry University (Natural Science Edition), 38, 175-180.

[5] Li, J., Wang, Z., Li, Y.C., Gai, J.Y., Huang, Z.W. and Wu, R.L. (2014) A Novel QTL Mapping Model for Allometric Growth and Pleiotropic Extension. Journal of Nanjing Forestry University (Natural Science Edition), 38, 35-39.

[6] Obouayeba, S.E.A. (1997) Contribution of the Dynamic of the Vegetative Growth of Hevea brasiliensis to the Determination of Tapping Norms. Proceedings of Three IRRDB Symposia on Hevea, Ho Chi Minh City, 14-15 October 1997, 71-79.

[7] Chandrasekhar, T.R. (2012) Evaluation of Unconstrained and Constrained Mathematical Functions to Model Girth Growth of Rubber Trees (Hevea brasiliensis) Using Young Age Measurements. Journal of Forestry Research, 23, 365375. http://dx.doi.org/10.1007/s11676-012-0272-2

[8] Philippe, T. and Loïc, P. (1998) Modelling the Influence of Assimilate Availability on Root Growth and Architecture. Plant and Soil, 201, 307-320. http://dx.doi.org/10.1023/A:1004380021699

[9] Tian, Y.H., Yue, H., Long, Y.F. and Chen, G.Y. (2012) Application of the FracRoot Model in the Root Study of Rubber Tree Species. Chinese Journal of Tropical Crops, 33, 33-36.

[10] Zhu, X.D. (1995) Relationship between Yield of Rubber Tapping Trees per ha and Planting Density. Chinese Journal of Tropical Crop Science and Technology, 33, 45-46.

[11] Zhou, Z.Z., Zheng, H.S., Yin, G.T., Yang, Z.J. and Chen, K.T. (1995) Biomass Equations for Rubber Tree in Southern China. Forest Research, 8, 624-629.

[12] Tang, J.W., Pang, J.P., Chen, M.Y., Guo, X.M. and Zeng, R. (2009) Biomass and Its Estimation Model of Rubber Plantations in Xishuangbanna, Southwest China. Chinese Journal of Ecology, 28, 1942-1948.

[13] Zhou, Z.D. and Liu, G.H. (1990) Logisti-Markov Prediction Model—Rubber Unit Area Yield Forecast. Science and Technology of Fujian Tropical Crops, 1, 7-10.

[14] Hu, Y.H., Wang, K., Shu, Y.T. and Wu, Y.G. (1982) Studies on Photosynthesis of Hevea Population II . A Mathematical Model for Estimating the Photosynthetic Output of Hevea Population. Chinese Journal of Tropical Crop Science and Technology, 3, 41-48.

[15] Xie, G.S., Chen, B.Q., Wang, J.K., Wu, Z.X. and Huang, W.F. (2010) Studies on the Simulation Model of Photosynthesis and Dry Matter Accumulation for Rubber Tree. Chinese Agricultural Science Bulletin, 26, 317-323. 
[16] Tang, Q.Y. and Feng, M.G. (2009) DPS Data Processing System: Experimental Design, Statistical Analysis, and Data Mining. Science Press, Beijing, 205-1024.

[17] Huang, Z.L., Pang, S.L., Hao, H.K., Peng, Y.H. and Wei, X.J. (2011) Study on Seedling Growth Rhythm of Zenia Insignis as Valuable Fast-Growing Native Tree Species in Guangxi. Journal of Southwest Forestry University, 31, 6-9.

[18] Huang, Z.L., Hao, H.K., Pang, S.L., Peng, Y.H. and Cao, Y.Y. (2012) A Study on the Seedling Growth Rhythm of Castanopsis hystrix among Provenince. China Forestry Science and Technology, 26, 24-28.

[19] Daniel, B. and Yves, C. (2007) Plant Architecture: A Dynamic, Multilevel and Comprehensive Approach to Plant Form, Structure and Ontogeny. Annals of Botany, 99, 375-407. http://dx.doi.org/10.1093/aob/mcl260

[20] Stephen, G.P. (2008) Vegetative Growth. Physiology of Woody Plants. 3rd Edition, Academic Press, Waltham, 39-86. http://dx.doi.org/10.1016/B978-012088765-1.50004-X

[21] Guilherme, A.P.S., Lígia, R.L.G., Cecília, K.V., André, L.B.O. and Paulo, S.G. (2014) Annual Growth Increment and Stability of Rubber Yield in the Tapping Phase in Rubber Tree Clones: Implications for Early Selection. Industrial Crops and Products, 52, 801-808. http://dx.doi.org/10.1016/j.indcrop.2013.12.010

[22] Rodrigo, V.H.L., Stirling, C.M., Silva, T.U.K. and Pathirana, P.D. (2005) The Growth and Yield of Rubber at Maturity Is Improved by Intercropping with Banana during the Early Stage of Rubber Cultivation. Field Crops Research, 91, 23-33. http://dx.doi.org/10.1016/j.fcr.2004.05.005

[23] Zhou, L.J., Wang, J., Chen, X.H. and Lin, W.F. (2013) A Comparative Study on the Different Budling of Hevea brasiliensis in the Immature Period. Chinese Agricultural Science Bulletin, 29, 26-29. 
Scientific Research Publishing (SCIRP) is one of the largest Open Access journal publishers. It is currently publishing more than 200 open access, online, peer-reviewed journals covering a wide range of academic disciplines. SCIRP serves the worldwide academic communities and contributes to the progress and application of science with its publication.

Other selected journals from SCIRP are listed as below. Submit your manuscript to us via either submit@scirp.org or Online Submission Portal.
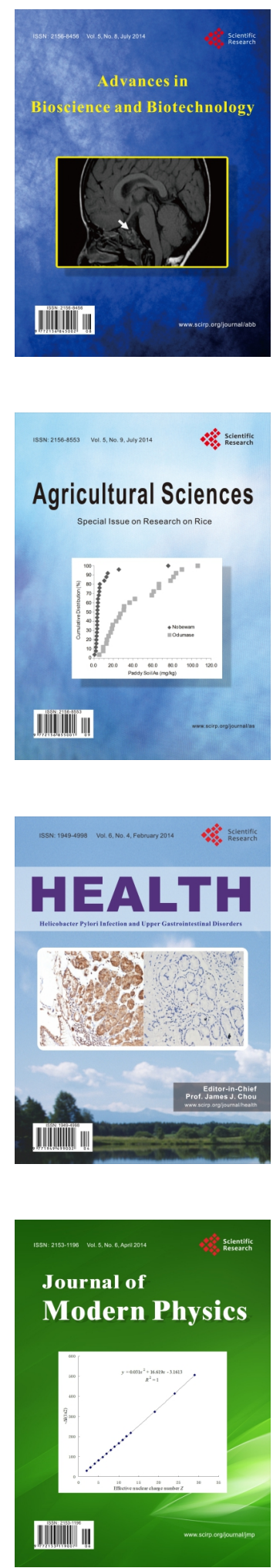
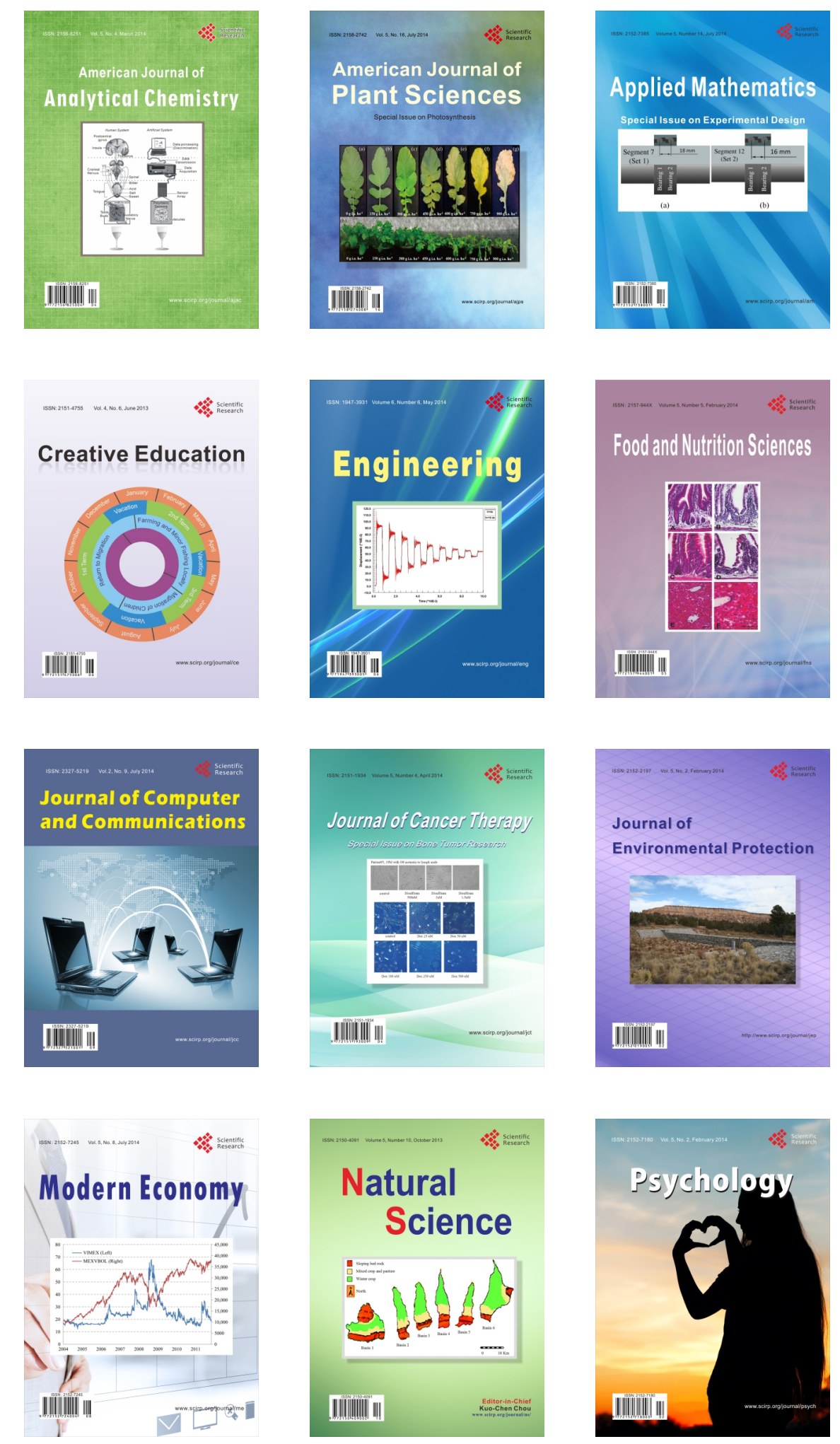